Reproduced, with permission, from Compendium of Cucurbit Diseases, pp. 34-35, 1996. The American Phytopathological Society, St. Paul, MN, U.S.A.

\title{
Bacterial Fruit Blotch of Cucurbits
}

\section{R. X. Latin, Department of Botany and Plant Pathology, Purdue University, West Lafayette, IN 47907}

Posted 2 June 2000. Plant Health Progress doi:10.1094/PHP-2000-0602-01-HM.

Bacterial fruit blotch was first reported in the Mariana Islands in 1988. It appeared in commercial watermelon fields in the United States in 1989, with isolated severe outbreaks in Florida, South Carolina, and Indiana. The disease has since been reported in several other states in the eastern United States. Although other cultivated cucurbits are susceptible to infection, significant losses have been reported only in watermelon crops.

\section{Symptoms}

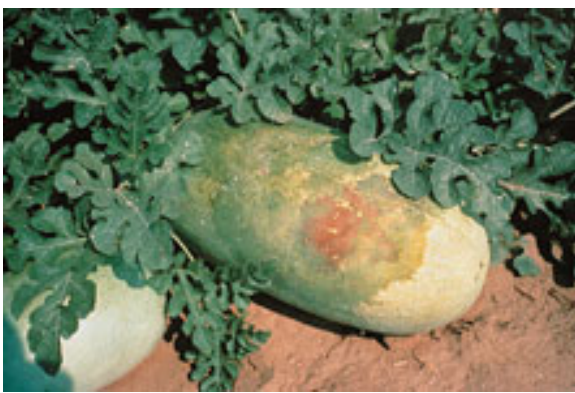

Fig. 1. Bacterial fruit blotch on watermelon caused by a bacterium of on uncertain taxonomy.

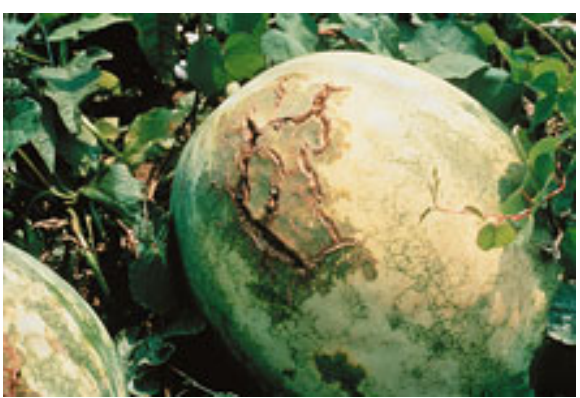

Fig. 2. Fruit cracks associated with blotch.

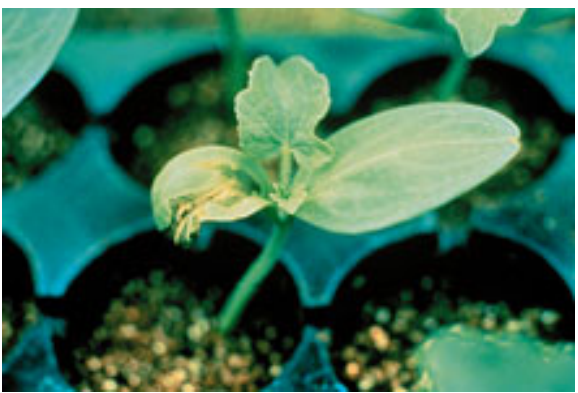

Fig. 3. Infected seedlings
The characteristic symptom of bacterial fruit blotch of watermelon is a dark olive green stain or blotch on the upper surface of the fruit (Fig. 1). The blotch is first noticeable as a small water-soaked area, less than $1 \mathrm{~cm}$ in diameter, but it rapidly expands to cover much of the fruit surface in 7-10 days. As the blotch increases in size, the area around the initial infection site becomes necrotic. In advanced stages of lesion development, the epidermis of the rind ruptures, and frequently a transparent or amber-colored substance is exuded (Fig. 2). Fruit lesions rarely extend into the flesh of watermelon, but when this occurs, the bacteria contaminate the seeds. Secondary rotting organisms are responsible for the ultimate decay and collapse of the fruit. Rapid expansion of fruit lesions usually occurs during the few weeks prior to harvest. Bacterial fruit blotch also affects melon, often resulting in water-soaked pits on the fruit surface, but the disease is best characterized in watermelon.

The fruit blotch bacterium also infects leaves, although foliage surrounding infected fruit may appear healthy to the untrained eye. Leaf lesions are small, dark brown, somewhat angular, and often inconspicuous. During periods of high humidity, the margins of leaf lesions often appear water-soaked.

Because the pathogen is seedborne, and because a significant portion of commercial watermelon fields are planted with seedlings raised in greenhouses or other transplant production facilities, recognition of symptoms on seedlings is important. The initial symptom on seedlings is a water-soaked area on the undersides of the cotyledons (Fig. 3). As the cotyledons expand, the lesion becomes necrotic and often extends along the length of the midrib. Lesions on young true leaves are small and dark brown and may have chlorotic halos. Seedlings infected with fruit blotch often do not collapse and die in the greenhouse, but the incidence of foliar symptoms will increase slowly in a warm, moist environment.

\section{Causal Organism}

The taxonomy of the causal agent of bacterial fruit blotch remains uncertain. The pathogen is a gram-negative, rod-shaped, motile bacterium with single polar flagellum. It was described as being very similar but not identical toPseudomonas pseudoalcaligenes Stanier subsp. citrulli Schaad et al., a watermelon seedling pathogen reported in 1979, which is now taxonomically classified as Acidovorax avenae subsp. citrulli (Schaad et al.) Willems et al. However, the seedling bacterium does not produce a hypersensitive response in tobacco leaves and does not cause symptoms in watermelon fruit, whereas the fruit blotch bacterium produces a hypersensitive response in tobacco and causes seedling blight, leaf lesions, and fruit symptoms in watermelon. Fatty acid methyl ester analysis also indicates that the seedling bacterium and the fruit blotch bacterium are very similar but not identical. The taxonomic distinction between these two bacteria is not clear.

\section{Disease Cycle}

The bacterial fruit blotch pathogen is seedborne. Internal and external contamination of the seed coat may occur; however, there is no evidence of infection within the seed. Contaminated seed results in infected seedlings, which serve as important sources of secondary inoculum, especially in transplant production facilities, where warm, humid conditions, overhead irrigation, and a canopy of susceptible plant tissue favor pathogen dispersal and disease increase. Secondary 
infections occur after bacteria gain entrance into plant tissues via natural openings, such as stomates. In the field, the bacteria produced on lesion surfaces are rain-splashed onto newly developed leaves and neighboring plants.

Although a very high proportion of leaves on a plant may exhibit symptoms of bacterial fruit blotch, the severity of symptom expression on individual leaves is very slight. Infection does not result in wilt, defoliation, vine blight, or vine collapse. There is no evidence of systemic infection; attempts to isolate the bacterium from surface-sterilized vines or peduncles of infected fruit have been unsuccessful. Leaf lesions are most important as a primary source of bacteria for fruit infection. Lesions on mature fruit are an additional source of secondary inoculum in the field. Bacteria associated with fruit infections filter down through the flesh of the watermelon, where they become associated with the seed.

In addition to overwintering contaminated seed, the pathogen may overwinter in infested rind. Infested crop residue, volunteer watermelon plants from contaminated seed, and infected wild cucurbits, especially wild citron, are important potential sources of primary inoculum in a subsequent crop season. Seed transmission has also been demonstrated in citron.

\section{Epidemiology}

The increase and spread of fruit blotch is associated with the warm, moist conditions common to watermelon production areas and transplant production facilities in the eastern United States. Because the disease is newly discovered, research investigating its epidemiology is still in progress. Preliminary results suggest that the pathogen is splashdispersed and that successful infection can occur with leaf wetness periods of only 30 min at temperatures around 26?C. The rate of disease spread can be especially high in transplant production facilities where environmental conditions and the lack of host resistance favor rapid disease progression.

\section{Control}

Control of bacterial fruit blotch depends on the availability of uncontaminated watermelon seed. Hot water and bleach treatments are not effective in eliminating contamination from infested seed. Partial genetic resistance may occur in some watermelon cultivars; however, most are very susceptible to foliar infection.

Fields infested with the fruit blotch pathogen should be plowed in the fall, and volunteer watermelon seedlings should be controlled during the following year to eliminate inoculum sources. Fields should be rotated out of cucurbits for 3 years or more.

Standard greenhouse sanitation procedures should be employed, especially in structures where outbreaks of fruit blotch have occurred.

If field spray programs are begun prior to fruit-set, periodic applications of copper sprays may result in a reduced rate of spread of the disease, but they may be of minimal value under conditions highly favorable for disease development.

\section{Selected References}

Hopkins, D. L. 1989. Bacterial fruit blotch of watermelon: A new disease in the eastern USA. Pages 74-75 in: Proc. Cucurbitaceae '89: Evaluation and Enhancement of Cucurbit Germplasm. C. E. Thomas, ed. U.S. Vegetable Laboratory, Charleston, SC.

Hopkins, D. L. 1990. Differences in cultivar resistance to bacterial fruit blotch of watermelon. (Abstr.) Phytopathology 80:435.

Rane, K. K., and Latin, R. X. 1992. Bacterial fruit blotch of watermelon: Association of the pathogen with seed. Plant Dis. 76:509-512.

Somodi, G. C., Jones, J. B., Hopkins, D. L., Stall, R. E., Kucharek, T. A., Hodge, N. C., and Watterson, J. C. 1991. Occurrence of a bacterial watermelon fruit blotch in Florida. Plant Dis. 75:1053-1056.

Sowell, G., Jr., and Schaad, N. W. 1979. Pseudomonas pseudoalcaligenes subsp.citrulli on watermelon: Seed transmission and resistance of plant introductions. Plant Dis. Rep. 63:437-441.

Wall, G. C., Santos, V. M., Cruz, F. J., and Nelson, D. A. 1990. Outbreak of watermelon fruit blotch in the Mariana Islands. Plant Dis. $74: 80$. 